УДК: $343.72(575)$

Научная статья

DOI 10.18101/2658-4409-2020-3-43-47

\title{
МОШЕННИЧЕСТВО ПО УГОЛОВНОМУ КОДЕКСУ РОССИИ, СРЕДНЕЙ АЗИИ И СТРАН АТР
}

\author{
(ㄱ Садыков Николай Будаевич \\ доцент, \\ Бурятский государственный университет имени Доржи Банзарова \\ Россия, 670000, г. Улан-Удэ, ул. Сухэ-Батора, 6 \\ sadykovnb@mail.ru
}

\begin{abstract}
Аннотация. Автор в статье исследует проблемы классификации способов совершения мошенничества в странах Азиатско-Тихоокеанского региона, в государствах Средней Азии и Российской Федерации. Обращает внимание на специфику потерпевших при использовании преступниками мошеннических действий с помощью современных цифровых устройств. В качестве передового положительного опыта автор предлагает обратить внимание на особенности законодательного закрепления форм противодействия мошенническим действиям в таких странах, как Япония, Южная Корея, КНР. Для раскрытия темы исследования автор использует следующие методы познания: сравнительно-правовой, исторический, системный. Также предлагается ввести в ст. 159 УК РФ дополнительный квалифицирующий признак, если мошенничество совершено в отношении лиц пожилого возраста и несовершеннолетних.

Ключевые слова: Уголовный кодекс; мошенничество; санкции; статистика; телефонное мошенничество.
\end{abstract}

\section{Для цитирования}

Садыков Н. Б. Мошенничество по Уголовному кодексу России, Средней Азии и стран АТР // Вестник Бурятского государственного университета. Юриспруденция. 2020. Вып. 3. С. 43-47.

По Уголовному кодексу Российской Федерации, стран АТР и Средней Азии мошенничеством признается хищение чужого имущества или приобретение права на чужое имущество путем обмана или злоупотребления доверием. Таким образом, мошенничество как уголовное деяние отличается от других способов хищения тем, что оно совершается путем обмана.

Остановимся на криминалистической характеристике личности мошенников. Это конгломерат наглости, ловкости и цинизма, а заодно безмерной жажды «дармовой» наживы, вера в безнаказанность и фатализм. По способам хищения они все делились на шесть основных групп [3, с. 165; 6, с. 63].

Шулеры - карточные мошенники со стародавними, стойкими традициями. Обман реализуется определенными приемами - передергиванием карт, съемкой колоды под определенную карту, креплением карт и просто «ловкостью рук».

Кукольники - имитируют свертки с деньгами, кошельки, упаковки с ценным товаром и т. п. В зависимости от вида «куклы» разыгрывается та или иная 
постановка, но кульминация всегда одинаковая: потерпевший вместо ожидаемых благ получает «куклу».

Шнеерзоны - торговцы фальшивыми ценностями, как правило, ювелирными изделиями, антиквариатом либо произведениями искусства.

Фармазоны - специализируются на фальсификации драгоценных камней, прежде всего бриллиантов; их отличает высочайший артистизм и незаурядный интеллект.

Сценаристы - мастера инсценировок: имитации ограбления, нанесения телесных повреждений, автомобильных аварий и т. д. Активно используются инсценировки и для проведения с целью ограбления обысков, досмотра транспортных средств (в форменной одежде органов внутренних дел).

Аферисты - наиболее распространенная разновидность мошенников, выдают себя за «деловых людей», умело входят в доверие, получают от клиентов деньги, ценности «под обещание» и исчезают. Ныне к перечисленным прибавилось множество других «специализаций», среди них и телефонные мошенники, а также с использованием компьютерной технологии.

Появление и распространение мошенничества как в России, так и в других странах связывается с развитием торговых отношений, именно среди купцов. Затем хищением путем обмана стали заниматься и другие слои населения. А с развитием научно-технического прогресса способ мошенничества был усовершенствован.

Статистические данные о мошенничестве в России, странах Центральной Азии и Азиатско-Тихоокеанского региона складывается следующим образом [5, c. 1282]. В России мошенничество имеет тенденцию постоянного роста. Например, за последние 5 лет, по официальной статистике прокуратуры, уровень мошенничества возрос со 166 до 222 тыс. зарегистрированных преступлений. Большую долю в этом занимает мошенничество, совершаемое с использованием компьютерных и телекоммуникационных технологий [7, с. 131].

Данный вид мошенничества захлестнул и другие страны. Так, в Южной Корее среди видов мошенничества популярным является так называемое voice fishing (голосовая рыбалка). Это когда по телефону связываются с человеком от имени сотрудников банка и т. д., в результате списываются со счета денежные средства или становится доступной личная информация. Аналогичная ситуация прослеживается в Китае и Японии, где также получили широкий размах преступления с использованием компьютерных сетей - так называемые сетевые или киберпреступления [5, с. 1283].

В Монголии, наоборот, наблюдается снижение мошенничества на 8,2\%. Как в России, так и в странах АТР увеличивается число случаев мошенничества, где объектом посягательства становятся пожилые люди. По Уголовному кодексу Российской Федерации [4, с. 121] мошенничество включено в раздел VIII, гл. 21 «Преступление против собственности», в бывших советских республиках Средней Азии (Казахстан, Таджикистан, Киргизия) мошенничество включено в раздел «Преступление против экономики», тогда как в Турции, Японии и Республике Корея - в отдельную главу «Мошенничество и банкротство» (Турция) или «Преступление, связанное с мошенничеством и вымогательством» (Япония и Республика Корея). 
В Особенной части УК Российской Федерации и УК стран бывшего Советского Союза предусмотрены конкретные статьи. Так, по УК Республики Таджикистан (ст. 247), Республики Казахстан (ст. 177), Кыргызстан (ст. 166) и России (ст. $159,159-1,159-2,159-3,159-4,159-5,159-6)$ мошенники несут ответственность в основ- ном за причинение материального ущерба в крупном и особо крупном размере, не считая квалифицирующего признака «группа лиц».

К наказанию за мошенничество в таких странах, как Турция (ст. 503-505), Япония (ст. 246, 246-11, 247, 248), Республика Корея (ст. 347, 347-2, 348), подошли несколько иначе. Они в квалифицирующий признак включили несовершеннолетие и слабоумие лица, в отношении которых было совершено мошенничество. Причем в Японии и Республике Корея предусмотрено наказание сроком не более 10 лет по всем статьям о мошенничестве [5, с. 1284].

Если проанализировать статистические данные о мошенничестве, совершенном в Республике Бурятия за последние 5 лет, то это будет выглядеть следующим образом ${ }^{1}$ :

- в 2015 г. на территории республики за мошенничество осуждены лица по 1109 делам;

- в 2016 г. в суды направлено 975 дел;

- в 2017 г. произошел скачок мошенничества, что составило 1245 дел;

- примерно такой же уровень преступлений в сфере мошенничества отмечался и в 2018 г. - 1246 дел;

- в 2019 г. вновь произошел резкий скачок — до 1498 преступлений.

В основном мошенники при изъятии денежных средств стали активно использовать достижения научно-технического прогресса - сотовые телефоны. Потерпевшими по такому роду мошенничества чаще всего становятся люди пожилого возраста [2, с. 1336]. Это самые незащищенные слои населения, так как в силу преклонного возраста они становятся сердобольными и доверчивыми людьми. В эту категорию людей входят и несовершеннолетние. Поэтому государство, в лице правоохранительных органов, в первую очередь обязано защищать от преступного посягательства именно эти слои населения.

Таким образом, из вышеприведенной статистики видно, что борьбу с мошенничеством согласно УК России мы проигрываем. Несмотря на то, что целью уголовного наказания является предупреждение или удерживание на минимальном уровне преступных деяний. Ведь от этого во многом зависит благополучие граждан России и его комфортное проживание.

Как переломить такую негативную ситуацию? Для этого необходимо обратиться к опыту зарубежных стран. Приведем примеры борьбы с мошенничеством в Китае, Южной Корее и Японии. Нам всем известно, что в Китае очень жестко относятся к преступным проявлениям. Это одна из стран, которая еще не отказалась от смертной казни. Хотя в настоящее время и в этой стране поднимается вопрос об ее отмене. Тем не менее путем жестких санкций Китай добился в этом направлении больших успехов. В результате за 2019 г. количество уголовных преступлений снизилось на 5,2\%, количество тяжких преступлений — на $10 \%$.

${ }^{1}$ В МВД по Республике Бурятия состоялось заседание коллеги по итогам работы за 2019 г. URL: https://xn--b1aew.xn--p1ai/reports/2/ (дата обращения: 09.11.2020). 
По сообщению NA REGNUM, в Китае с начала 2019 г. раскрыто 94 тыс. преступлений, связанных с телефонным мошенничеством, что на $30,3 \%$ больше, чем годом ранее за аналогичный период.

В Южной Корее уровень преступности значительно ниже, чем в других странах, потому что они организовали жесткий контроль со стороны социума. Соседи друг друга знают очень хорошо, поэтому совершить какое-либо преступление сложно. Во-вторых, корейцы чтят закон и правила (принцип послушания и конфуцианство). В-третьих, у них нет времени нарушать закон. Они постоянно заняты на работе или учебе или готовятся к поступлению в вузы. В основном преступления совершаются в бедных и населенных иностранцами и мигрантами районах.

Япония считается страной, где к росту преступлений относятся более строго. Например, к преступлениям, составляющим более половины общего числа краж (велосипедные кражи). Полагаем, что если уровень преступлений, связанных с мошенничеством, станет увеличиваться, то санкции в Уголовном кодексе Японии начнут ужесточаться. В России, как и в странах бывшего постсоветского пространства, борьба с мошенничеством находится в плачевном состоянии, в результате мошенничество не только не снижается, а наоборот, процветает, особенно в настоящее время, да еще и в период всеобщей пандемии.

Таким образом, исходя из анализа борьбы с мошенничеством необходимо в ст. 159 УК РФ ввести новый квалифицирующий признак «...в отношении лиц пенсионного возраста и несовершеннолетних», и как в Японии и других странах срок увеличить до 15 лет. С этим преступлением необходимо бороться жестко, искореняя низменные желания у неблагополучных лиц, стремящихся к легкой наживе, принося страдания и горе другим людям.

\section{Литература}

1. Барчуков В. К. Разграничение мошенничества в сфере компьютерной информации с иными составами мошенничества // Проблемы экономики и юридической практики. 2017. № 4. С. 112-114.

2. Гарипова Р. А. Потерпевший при расследовании мошенничества // Наука ЮУрГУ. Материалы 67-й научной конференции. 2015. С. 1336-1340.

3. Горобченко С. В. Криминалистическая классификация способов совершения мошенничества // Право и образование. 2008. № 8. С. 165-172.

4. Старицын В. В., Бражник С. Д. Мошенничество: новеллы уголовного законодательства // Молодая наука-2015: материалы VI регион. науч. конф. студентов и аспирантов. Пятигорск, 2015. С. 121-125.

5. Теплова Д. О. Понятие и виды мошенничества в международном праве // Административное и муниципальное право. 2015. № 12(96). С. 1282-1286.

6. Чечель Г. И., Третьяк М. И. Мошенничество: вопросы квалификации // Общество и право. 2015. № 3(53). С. 63-65.

7. Чупрова А. Ю. Проблемы квалификации мошенничества с использованием информационных технологий // Уголовное право. 2015. № 5. С. 131-134. 
FRAUD UNDER THE CRIMINAL CODE OF RUSSIA, CENTRAL ASIA AND THE ASIA PACIFIC REGION

Nikolay B. Sadykov

A/Prof.,

Dorzhi Banzarov Buryat State University

6 Sukhe-Batora St., Ulan-Ude 670000, Russia

sadykovnb@mail.ru

Abstract. The author in the article examines the problems of classification of methods of committing fraud in the countries of the Asia-Pacific region, in the states of Central Asia and the Russian Federation. Draws attention to the specifics of victims when criminals use fraudulent activities using modern digital devices. As an advanced positive experience, the author proposes to pay attention to the peculiarities of legislative consolidation of forms of counteraction to fraudulent actions in countries such as Japan, South Korea, and China. In addition to the Asia-Pacific countries, the author examines the specifics of legislative consolidation in the criminal codes of a number of Central Asian countries. To reveal the research topic, the author uses the following methods of cognition: comparative legal, historical, systemic. It is also proposed to supplement Article 159 of the Criminal Code of the Russian Federation with an additional qualifying feature, if it is committed in relation to elderly people and minors.

Keywords: criminal code; fraud; sanctions; statistics phone fraud.

Статья поступила в редакцию 20.11.20; одобрена после редактирования 01.11.20; принята к публикации 05.11.20. 